\title{
The Time of His Life
}

\author{
Petrarch's Marginalia \\ and \\ Rerum vulgarium fragmenta 23
}

\author{
Teodolinda Barolini
}

\begin{abstract}
Petrarch's draft notebooks, MS Vaticano Latino 3196, contain marginalia that often record the date and time of composition of a poem, along with date and time of transcription into Vaticano Latino 3195 (the volume of collected poems that became known to posterity as Canzoniere), interleaved with personal notations. I examine these marginalia, haunting in their immediacy and intimacy, for what they can tell us about Petrarch's poetics, with particular attention to the notations to $\mathrm{Nel}$ dolce tempo de la prima etade, the poem that became number 23 and the first canzone of the Rerum vulgarium fragmenta.
\end{abstract}

$\mathrm{T}$

HERE IS NO AUTHOR I CAN THINK OF IN WHOSE WORK TIME HAS a more privileged place than Petrarch — and I am including in my tally works of such explicit time-centeredness as Proust's À la recherche du temps perdu. Titles were not as significant in the fourteenth century as they were in the twentieth, but in fact Petrarch's own title for the lyric sequence traditionally called Canzoniere does thematize time, albeit in a fashion more oblique than Proust's title. The title Rerum vulgarium fragmenta (Fragments of Vernacular Matters), uses the idea of fragmentation to highlight the metaphysical basis of time, the medium that fragments us, that makes us multiple and metamorphic, that robs us of ontological stillness and wholeness. The title Rerum vulgarium fragmenta also brilliantly reflects the process of material construction, whereby Petrarch built his lyric collection by transcribing "fragments" - poems from his draft notebooks — into a unified collection, a standing order. The process by which Petrarch materially constructed his lyric collection (and also, significantly, his epistolary collections) in itself is dialectically enmeshed with Petrarch's abiding metaphysical concerns, and thus the title Rerum vulgarium fragmenta reflects 
both the material and the metaphysical, the author's hand and the author's thought.

We can think of time in Petrarch's work in a number of ways. First, and most obvious, is the continual thematic invocation of time and its passing, present in his poems from first to last, but not just in his poems; time is thematized in all of Petrarch's writings, from the Latin to the vernacular, from the philosophic to the erotic, from the humanistic to the religious. My favorite representative of this vast thematic current is this passage from one of the letters:

Ecce ad hunc locum epystole perveneram deliberansque quid dicerem amplius seu quid non dicerem, hec inter, ut assolet, papirum vacuam inverso calamo feriebam. Res ipsa materiam obtulit cogitanti inter dimensionis morulas tempus labi, meque interim collabi abire deficere et, ut proprie dicam, mori. Continue morimur, ego dum hec scribo, tu dum leges, alii dum audient dumque non audient; ego quoque dum hec leges moriar, tu moreris dum hec scribo, ambo morimur, omnes morimur, semper morimur [. . . . ${ }^{1}$

(Having reached this point in the letter, I was wondering what more to say or not to say, and meanwhile, as is my custom, I was tapping the blank paper with my pen. This action provided me with a subject, for I considered how, during the briefest of intervals, time rushes onward, and I along with it, slipping away, failing, and to speak honestly, dying. We all are constantly dying, I while writing these words, you while reading them, others while hearing or not hearing them; I too shall be dying while you read this, you are dying while I write this, we both are dying, we all are dying, we are always dying [. . .].)

I find this passage compelling, because in it Petrarch makes the time of writing and the time of being literally the same: the time of his life. And, to the degree that these words reach out to us and spell our own mortality, they spell the time of our lives as well.

After the category of theme, we can move to the category of form: Petrarch was deeply invested in the invention (or re-invention) of genres that are temporally charged, that problematize narrativity and hence time:

1. Rossi v 942, 220 (Fam. 24.1.26-27). The translation is Aldo Bernardo's (1985, 312). In fact, Petrarch's own introductory rubric announces the letter's central topic: "Ad Philippum Cavallicensem epyscopum, de inextimabili fuga temporis" ("To Philippe, Bishop of Cavaillon, on the incredible flight of time" [Rossi 1942, 213]). 
the lyric sequence (Rerum vulgarium fragmenta) and the epistolary collection (Familiares, Seniles). Within the already temporally charged lyric sequence, he cultivated meters that are obsessive in their manipulation of time, for instance the sestina. ${ }^{2}$ At a micro-level as well, his lyrics are magisterial in their manipulation of time through the use of time-engaged tropes such as chiasmus and hysteron proteron as well as in their syntax and grammar, as is clear from the study of his deployment of tense. ${ }^{3}$

All of these examples are reflected in the material record: Petrarch left behind clear documentation of the ways he went about writing his lyric sequence that shows us how his method of composition in itself reflects his awareness of time and its passing. Never is this more apparent than in his remarkable marginalia in the paper and parchment MS Vatican Latino 3196, all in Petrarch's hand, of which we possess eighteen chartae devoted to his lyrics (and those of others), pieces of his Triumphus Eternitatis, and a fragment from the letter Familiaris 16.6. Often on these holograph chartae we find as well his recording of the date and time of composition, along with personal notations and dates and times of transcription that are haunting in their immediacy and intimacy. In the following pages I will focus on these marginalia and particularly on the record of composition regarding a poem that his marginal comments indicate was very special to him and that eventually became number 23 of the Rerum vulgarium fragmenta: the first canzone of the collection, Nel dolce tempo de la prima etade.

On the first charta from Petrarch's draft notebooks (now Latino 3196), we can see a sampling of his marginalia. ${ }^{4}$ In the upper right corner, Petrarch noted the date in very precise detail: "1366. Sabato an[(te)] [lu]ce $(\mathrm{m})$, dece $(\mathrm{m})$ br(is) 5" ("Saturday, December 5, 1366, before daylight"). ${ }^{5}$ By noting the year, the date, the day of the week, and even the time of day, he

2. See Barolini 1989, now in Barolini 2006, 193-223.

3. On chiasmus and in particular Rvf 266, see Barolini 2009a, 219-21. On tense in the Rvf see TADDEO 1983. After a brief section on "Il tempo come tema nelle Rime", Taddeo deals with "Il tempo come categoria formale nei sonetti", showing how Petrarch employs tense to obtain "quello che è il carattere specifico della poesia petrarchesca, la profondità della prospettiva temporale" (75).

4. Transcriptions and translations of these marginalia are my own from MS Vaticano Latino 3196. Thanks to Wayne Storey for his assistance with the transcriptions and to Julie Van Peteghem for her assistance with the translations. For editions of Petrarch's MS Latino 3196, see Romanò 1951 and, more recently, Paolino 2000. See as well Salvo Cozzo's photographic edition (1895).

5. Petrarch's frequent abbreviations are expanded in parentheses. Square brackets indicate conjecture. See Paolino 2000, 175 for the reconstruction — through Ubaldini 1642 and Appel 1891 — of this annotation now faded with time. 
situates this transcription within the flow of time, registering quite literally the time of his life. ${ }^{6}$ Above the first sonnet on c. 1r, Oltra l'usato modo, to the left, he indicates that the transcribed poem is by his friend Sennuccio del Bene with the notation "Respo(n)sio Se(n)nucij n(ost)ri" ("Reply of our Sennuccio"). We should note that one of the stories told by the marginalia of Vaticano Latino 3196 is the place of friendship at the very heart of Petrarch's most intimate life, his writer's workshop; in other words, the marginalia are also testaments to the place he accorded to friendship. Above the next sonnet, Se le parti del corpo mio destrutte, Petrarch wrote "Iacobus de Columna lomber(iensis) ep(iscopu)s" ("Giacomo Colonna bishop of Lombez"), indicating that the sonnet is by another friend, Giacomo Colonna.

Above the third sonnet transcribed on the recto of the same first charta of Vaticano Latino 3196, Mai non vedranno, which eventually became Rvf 322, Petrarch wrote "Responsio mea sera ualde" ("My response, late indeed"), a notation as haunting as any poem written by this poet of a nostalgia so cultivated and pronounced that at times it is even proleptic. ${ }^{7}$ In the postilla "Responsio mea sera ualde" there is, however, no prolepsis, just retrospection: the sonnet Mai non vedranno was written as a response to Giacomo Colonna's sonnet (Se le parti del corpo mio destrutte) congratulating Petrarch on receiving the laurel crown in 1341; Giacomo himself died in August 1341, before Petrarch was able to reply to his congratulations. Petrarch's postilla expresses regret for time lost and for a future forever tarnished by what he failed to do in the past. Not for Petrarch the cando optimism and psychological good health of staying focused on what we can control in the present, of leaving behind what is past and hence irreparable. All the regret and belatedness that mark human interactions - all the things we wish we had said before it was forever too late to say them - are contained in the spare notation "Responsio mea sera ualde".

On the verso of the second charta, we find Petrarch's notation made on 19 May 1368, in which he gives even more precise information about

6. We should bear in mind that Petrarch died in 1374 , so this postilla was written quite late in his life.

7. An example of proleptic nostalgia is found in canzone 126, Chiare, fresche et dolci acque, whose complex temporal shifts encompass the imagining of a future time ("Tempo verrà" [v. 27]) in which Laura will return to their shared past, their "usato soggiorno" (v. 28), with the result that the love that she never showed him in the past of the macrotext is shown in an imagined future recollection of a past that is created within the present of a microtext. Citations from the Rerum vulgarium fragmenta (Rvf) are taken from Contini [1964] 1972, bearing in mind STOREY 2004. 
"the time of his life", recording his insomnia: "1368. maij 19 uen(er)is, nocte (con)cub(ia). i(n)so(m)nis diu [ta(n)de(m) su]rgo (et) occ(ur)rit h(oc) uetustissimu(m) an(te) XXV a(n)nos" ("19 May 1368, Friday, in the middle of the night. Unable to sleep, I finally got up and this very old composition from 25 years ago presents itself" [O bella man, Rvf 199]). ${ }^{8}$ Here Petrarch tells us that a poem on which he was working in 1368 was first composed circa 1343, a quarter of a century earlier. Very important is the information recorded in the postilla not only about the temporal nature of Petrarchan composition but also about the self-consciously temporal nature of the process, as documented also in his notation on c. $7 r$ to the sonnets Per mirar Policleto and Quando giunse a Simon, which became Rvf 77 and 78: "tr(anscripti) isti duo i(n) ord(ine), p(ost) mille a(n)nos $1357 \mathrm{~m}$ (er)cur(ii) hora 3 noue(m)br(is) 29" ("These two were transcribed in order, after 1000 years, Wednesday 29 November 1357 at 9 a.m.”). Saying that he finally transcribed these sonnets into the standing order "post mille annos" is Petrarch's way of drawing attention to a process that he experienced as supremely temporal. He worked on his lyrics off and on for years and years, always conscious of time as the medium in which his work came to fruition: the very brine of life, the salt of existence in which his words were pickled and became "done", ready to be copied into the codex in which the ordered sequence was being constructed.

The sonnet Voglia mi sprona, Amor mi guida et scorge, appears on c. 5r. It eventually became number 211 in the Rerum vulgarium fragmenta, but according to Petrarch's notation — it almost failed to make the cut:

$\operatorname{Miru}(\mathrm{m}), \mathrm{h}(\mathrm{un}) \mathrm{c}$ ca(n)cell(atum) (et) da(m)natu(m) p(ost) m(u) ltos a(n)nos, ca(s)u relege(n)s, absoluj (et) tr(anscripsi) i(n) ord(ine) stati(m), no(n) obst(ante). $1369 \mathrm{Iu}(\mathrm{n})$ ii 22, hora 23, uen(er)is, pauc(a) p(ost)ea, die 27, i(n) uesp(er)is, mutauj fine[m] [. . .] h(oc) f[. . .] e(r)it $\mathrm{a}[\ldots]^{9}$

(Amazing. By chance rereading this deleted and rejected sonnet after many years, I readmitted it and transcribed it immediately into the order, notwithstanding [. . . F Friday 22 June 1369 at 5 a.m. A little later, the 27 th, in the evening, I changed the ending [. . . ]).

"Amazing" - "Mirum" — writes Petrarch, and it is truly amazing, for the ending of Voglia mi sprona, which Petrarch tells us he rewrote shortly after

\footnotetext{
8. See again Paolino 2000, 190 on the nineteenth-century origins of the conjectured "tandem su" before the codex's deterioration.

9. The postilla has for several reasons attracted paleographic and interpretative conjecture. See Paolino 2000, 213.
} 
readmitting it to his ordered collection, gives us the year of his falling in love, or as he puts it, of his entering the labyrinth: "Mille trecento ventisette, a punto / su l'ora prima, il dì sesto d'aprile, / nel laberinto entrai, né veggio ond'esca" ("One thousand three hundred twenty-seven, exactly at the first hour of the sixth day of April, I entered the labyrinth, nor do I see where I may get out of it" [Rvf 211.12-14]). Without this poem, which was "cancellatum" and "damnatum", we would be less able to reconstruct a chronology of the Canzoniere, because the all-important date "Mille trecento ventisette" (1327) is absent from the previous version. We begin to see a pattern emerging from the notations: the more time Petrarch spends working on a poem, the more time he incorporates into the poem. Given more time to think and work, he will move in the direction of language that is ever more temporalized, ever more freighted with time. The lengthy process of composition frequently records an emendation or correction or rewriting that is more temporally charged than the original variant.

This process, whereby an ever more temporalized diction emerges from a lengthy crucible of composition, is well displayed by the evolution of the canzone Nel dolce tempo de la prima etade (Rvf 23). This long canzone - at 169 verses it is longer than the longest canto of Dante's Commedia (Purgatorio 32 contains 160 verses), and the longest poem in Petrarch's collection - narrates the vicissitudes of the lover/poet as he undergoes a series of Ovidian transformations. ${ }^{10}$ Begun according to most estimates between 1327 and 1337, the last postilla is dated 1356, at least twenty years later. ${ }^{11}$ The recto and verso of charta 11 of the draft codex contain a number of Latin notations. We should note that their chronological order, in which we will consider them, is not the order in which they appear on the charta. ${ }^{12}$

The earliest transcription was actually written on the verso of c. 11 in the upper margin on 3 April 1350: "p(ost) m(u)ltos a(n)nos, 1350 Ap(r)

10. On the Ovidian transformations of Rvf 23, see BAROLIni 2009b, 50-53.

11. See Martinelli 1977, 50-79 for a review of the dating of the canzone. Of particular note is Petrucci's paleographic evaluation $(1967,29)$, which identifies Petrarch's adoption of a chancery minuscule hand between 1336 and 1337 as the script used for cc. 7-8, 9-10, 11r, and 16 of Vaticano Latino 3196. See also Petrucci 1967, 107-14 for a contextualization of this cursive hand that was essential to Petrarch in his letter writing and draft copies of his poetry.

12. The spatial orientation of the notations on c. $11 r$ and $v$ demonstrate that Petrarch's notes were less systematic than they were driven by the impulse of time and the poet's repeated attention to revision of the text. 
il(is) 3 mane: q(uia) triduo exacto $\mathrm{i}(\mathrm{n})$ stiti ad $\sup (\mathrm{re}) \mathrm{ma}(\mathrm{m}) \mathrm{manu}(\mathrm{m})$ $\mathrm{u}(\mathrm{u})$ lgariu(m), ne diuti(us) i(n)t(er) curas distrahar, visum e(st) (et) ha(n) $\mathrm{c}$ in ord(ine) tra(n)sc(r)ibere, $\mathrm{s}(\mathrm{ed}) \mathrm{p}(\mathrm{r})$ ius hic ex alijs papir[is] elicita(m) sc(r)ibere" ("1350, 3 April in the morning: because after three days I started to put the final touches on the [Rerum] vulgarium [fragmenta] so that I wouldn't be distracted any longer by troubles, it seemed a good idea to transcribe also this one in order, but before that to write here the one taken from other work sheets". As Dennis Dutschke notes, "Petrarch does not write transcripsi or scripsi, but instead visum est et hanc in ordine transcribere and elicitam scribere. He is not recounting a completed action, but rather projecting into the future and to what he intends to do". ${ }^{13}$

The second postilla belongs to a year later, 1351, and recounts that the poem has been completed, although not yet corrected, and defines it as "de primis inventionibus nostris", thus maintaining a symmetry between the poem's content ("Nel dolce tempo de la prima etade" [v. 1]) and its compositional chronology: "Expl(icit). s(ed) no(n)du(m) cor(recta), (et) e(st) de p(r)imis i(n)uent(i)o(n)ib(us) n(ost)ris. sc(r)ipt(um) hoc 1351 April(is) 28, Iouis, noct(e) (con)cu[bia]" ("Completed. But not yet corrected, and it is one of my first compositions. This was written on 28 April 1351, Thursday, in the middle of the night"). ${ }^{14}$ Six years after the first notation of 1350 , on 4 November 1356, Petrarch is working on verse 156, in the canzone's concluding stanza, and, after suggesting a variant to himself (" $u(e) l$ : I' narro il uero forse (et) c(etera)"), ${ }^{15}$ ruminates as follows: "1356 nove(m) br(is) 4, sero, du(m) cogito de fine har(um) nugar(um)" ("4 November 1356, at a late hour, while I thought about the ending of these trifles"). Six days later, on 10 November 1356, in the upper margin of c. 11r above the entire poem he notes that the canzone has finally - "post multos et multos annos" - been transcribed into the standing order: "tr(anscripta) in ord(ine) $\mathrm{p}$ (ost) $\mathrm{m}(\mathrm{u})$ ltos (et) $\mathrm{m}(\mathrm{u})$ ltos a(n)nos, $\mathrm{q}($ ui)b(us)da(m) mutat(is) 1356, Iouis $\mathrm{i}(\mathrm{n})$ uesp(er)is, 10 noue(m)br(is), mediol(ani)" ("transcribed in order after many, many years, with some changes, 1356 Thursday, in the evening, 10 November, Milan”).

13. See Dutschke 1977, 30. For this notation I have followed Dutschke, who prints "post multos annos" with what follows as one postilla on p. 29, whereas Paolino $(2000,842)$ transcribes them as two separate entries.

14. Added to the lower margin of c. $11 v$, "Explicit" is in an ink that is different from that in which he writes "sed nondum correcta [. . .] nocte concu[bia]". There is little way to measure the lapse of time between the two entries.

15. For additional but undated variants, see PAOLino 2000, 245. 
Again, there is a mirroring consonance between poem and life: as the poem is revised, as it changes in time, it becomes more temporalized, more existential, in a word, more Petrarchan. While on the whole Petrarch remains very faithful to his old poem, making revisions that are, as he says, hardly extensive ("quibusdam mutatis"), they are telling. There are, in my estimation, three major sites of revision. ${ }^{16}$ The first is in the second stanza, verses 30-31, where the poem comes to a first existential climax in "Lasso, che son! che fui!" (30). Although Petrarch toyed with this verse and registers many slight variants, from "Che son lasso et che fui" to "Or che son et che fui" to "Oimè che son che fui", he found from the outset and preserved the key existential meditation on the self captured by the two first-person verbs, one in the present, one in the passato remoto: sono and fui, a temporal contrast of which Petrarch was fond (cfr. Rvf 145.13, 252.13). This verse is paired with a verse that Petrarch however changed completely. Verse 31 mutates over time from a narrative statement, "Et come l'ò provato assai per tempo", to a proverbial sententia that reminds us that only from the perspective of the end can one presume to gauge one's life: "La vita el fin, e 'l dì loda la sera" (31).

Another occasion in which Petrarch revises in such a way as to highlight the existential is found in the same canzone at verse 80 , where his transformation into a stone mutates from "D'un freddo in vista sbigottito sasso" through "D'un freddo e 'n vista sbigottito sasso" to the final and uncanny "D'un quasi vivo et sbigottito sasso", where the stone's coldness is unpacked in order to get at the existential interstices that this poem probes: in the same way that he is caught between the present and the past in "Lasso, che son! che fui!", he is a stone, dead and inert, but somehow "quasi vivo" in the final version of verse 80.

The most profound revision occurs when, at the lowest ebb of the lover's fortunes, the poet interrupts the narrative: "Ma perché 'l tempo è corto, / la penna al buon voler non pò gir presso: / onde più cose ne la mente scritte / vo trapassando" ("But because time is short, my pen cannot follow closely my good will; wherefore I pass over many things written in my mind" [vv. 90-93]). He uses poetry to break violently free; because "living voices" - "le vive voci" — are forbidden him, he will cry out with paper and ink: "le vive voci m'erano interditte; / ond'io gridai con carta

16. A revision that I do not discuss is v. 28, where the rewriting of "Et quel ch'i' non provava in me quel tempo" conforms to the pattern of emphasizing the existential quandary of the self: "né rompea il sonno, et quel che in me non era, / mi pareva un miracolo in altrui" (vv. 28-29). 
et con incostro" ("Words spoken aloud were forbidden me; so I cried out with paper and ink" [vv. 98-99]). What he writes is a disclaimer of self in the language of metamorphosis; he who changes shapes, taking other identities through love, does not possess his self: "Non son mio, no" ("I am not my own, no" [100]). This quintessentially Petrarchan focus on self and identity was painstakingly achieved, for the earlier version of this verse is courtly and reminiscent of earlier stilnovist poetics: "Però con una carta et con enchiostro / Dissi: accorrete, donna, al fedel vostro!" "Therefore with a paper and ink I said: run, lady, to your faithful servant!") became "ond'io gridai con carta et con incostro: / Non son mio, no. S'io moro, il danno è vostro" ("so I cried out with paper and ink: I am not my own, no; if I die the fault is yours").

Far from merely technical, the marginal notations to Nel dolce tempo are, like the revisions we have just rehearsed, nothing short of existential; they afford Petrarch an ancillary venue, alongside a poem that in itself is all about time, in which to ruminate on the time of his life. From the first "post multos annos" to the last "post multos et multos annos", from the idea of the first of his compositions ("de primis inventionibus nostris") to the idea of the end of his collection ("de fine harum nugarum"), these are postille of ink that might as well be of blood.

Indeed, as Petrarch writes in Nel dolce tempo, the cries of his primal self are etched with ink on paper. But the poems are by definition, through the beautiful artifices of meter and rhetoric, and through the longue durée of their composition, necessarily somewhat belated, somewhat detached from the self that creates them. The truly primal cries are preserved in a primacy paradoxically reinforced by their occasional and secondary status in Vaticano Latino 3196. Etched in fading incostro on the fragile carte that preserve them, Petrarch's marginal notations are the authentic witnesses to what it means to "gridare con carta et con incostro" — to fight against time by embracing it with a writer's tools.

Columbia University

\section{Works Cited}

Appel, Carl. 1891. Zur Entwickelung Italienischer Dichtungen Petrarcas. Abdruck des Cod. Lat. Lat. 3196 und Mitteilungen auf den Handschriften Casanat. A III 31 und Laurenz. Plut. XLI N. 14. Halle: Niemeyer.

Barolini, Teodolinda. 1989. "The Making of a Lyric Sequence: Time and Narrative in Petrarch's Rerum vulgarium fragmenta”. Modern Language Notes 104: 1-38 (now in Barolini 2006, 193-223). 
2006. Dante and the Origins of Italian Literary Culture. New York: Fordham University Press.

. 2009a. "Petrarch as the Metaphysical Poet Who Is Not Dante: Metaphysical Markers at the Beginning of the Rerum vulgarium fragmenta (RVF 1-21)". In Petrarch and Dante, edited by Zygmunt BARAnski and Theodore CACHey, 195225. Notre Dame: University of Notre Dame Press.

- 2009b. "The Self in the Labyrinth of Time: Rerum vulgarium fragmenta". In Petrarch: A Critical Guide to the Complete Works, edited by Victoria Kігкнам and Armando Maggi, 33-62. Chicago: University of Chicago Press.

Bernardo, Aldo S., trans. 1985. Francesco Petrarca, Letters on Familiar Matters: Rerum familiarium libri XVII-XXIV. Baltimore: The Johns Hopkins University Press.

Dutschre, Dennis. 1977. Francesco Petrarca: Canzone XXIII from First to Final Version. Ravenna: Longo.

Martinelli, Bortolo. 1977. Petrarca e il Ventoso. Roma: Minerva Italica.

Paolino, Laura, ed. 2000. Francesco Petrarca, Il codice degli abbozzi. Edizione e storia del manoscritto Vaticano latino 3196. Milano-Napoli: Ricciardi.

Petrucci, Armando. 1967. La scrittura di Francesco Petrarca. Città del Vaticano: Biblioteca Apostolica Vaticana.

Romanò, Angelo. 1955. Il codice degli abbozzi (Vat. Lat. 3196) di Francesco Petrarca. Roma: Bardi.

Rossi, Vittorio, ed. 1942. Francesco Petrarca, Le Familiari. Vol. 4 (Libri XX-XXIV e Indici). Firenze: Sansoni.

Salvo Cozzo, Giuseppe, ed. 1895. Il manoscritto Vaticano Latino 3196, autografo di Francesco Petrarca, riprodotto in eliotipia. Roma: Martelli.

Storey, H. Wayne. 2004. "All'interno della poetica grafico-visiva di Petrarca”. Rerum vulgarium fragemnta. Codice Vat. Lat. 3195. Commentario all'edizione in fac-simile, edited by Gino Belloni, Furio Brugnolo, H. Wayne Storey, and Stefano Zamponi, 131-71. Roma-Padova: Antenore.

TAddeo, Edoardo. 1983. "Petrarca e il tempo". Studi e problemi di critica testuale 27: 69-108.

Ubaldini, Federico. 1642. Le rime di m. Francesco Petrarca estratte da un suo originale. Il trattato delle virtù morali di Roberto re di Gerusalemme. Il tesoretto di ser Brunetto Latini, con quattro canzoni di Bindo Bonichi da Siena. Roma: Stamperia del Grignani. 